\title{
Effectiveness of mindfulness sport performance enhancement (MSPE) on attention, planning and sport performance of elite Judoka
}

\author{
Meysam Shahhosseini ${ }^{1}$, Parviz Sabahi ${ }^{2}$, Shahrokh Makvand Hosseini ${ }^{3}$, Behruz Golmohammadi ${ }^{4}$ \\ 1- Master of Psychology, Department of Psychology, Semnan University, Semnan, Iran. \\ 2- Assistant Professor, Department of Psychology, Semnan University, Semnan, Iran (Corresponding Author). \\ E-mail: p_sabahi@semnan.ac.ir \\ 3- Associate Professor, Department of Psychology, Semnan University, Semnan, Iran. \\ 4- Assistant Professor, Department of Sport Sciences, Semnan University, Semnan, Iran.
}

Received: 21/02/2020

Accepted: 08/04/2020

\begin{abstract}
Introduction: In recent years, focus on processes and cognitive abilities of athletes has been considered by psychologists and cognitive science professionals.

Aim: The aim of this study was to evaluate the effectiveness of mindfulness sport performance enhancement (MSPE) on attention, planning and sport performance of elite Judoka.

Method: This study was a clinical trial with pretest, posttest, and follow-up assessment and also control group. The statistical population of this study consisted of elite Judoka of Tehran and by that 30 athletes were selected by convenience sampling with the mean age of $24.41 \pm 2.35$ and the sport history of $12.6 \pm 2.35$ in the both experimental and control groups. The experimental group received the Mindfulness-based intervention on athletic performance enhancement in the six weeks. All of the athletes were evaluated by Complex Stroop Test, Continuous Performance, London Tower and Sports Performance scale. In order to analyze the data, the repeated measures of MANOVA and ANOVA were used.
\end{abstract}

Results: The results of the present study showed that Mindfulness sport performance enhancement training significantly improved the Continuous attention, selective attention and planning $(\mathrm{p}<0.001)$. Also, the results of the athletic performance scale showed the growing trend of the athletes during intervention and follow-up process.

Conclusion: Therefore, Mindfulness sport performance enhancement training can be effective in improving cognitive and athletic performance and using that along with physical exercises will improve athletic performance of athletes.

Keywords: Judoka, Mindfulness, Attention, Athletic performance

How to cite this article : Shahhosseini M, Sabahi P, Makvand Hosseini Sh, Golmohammadi B. Effectiveness of mindfulness sport performance enhancement (MSPE) on attention, planning and sport performance of elite Judoka. Shenakht Journal of Psychology and Psychiatry. 2020; 7 (2): 37-52 .URL: http://shenakht.muk.ac.ir/article-1-780-fa.pdf

Copyright $(92018$ the Author (s). Published by Kurdistan University of Medical Sciences. This is an open access article distributed under the terms of the Creative Commons Attribution-Non Commercial License 4.0 (CCBY-NC), where it is permissible to download, share, remix, transform, and buildup the work provided it is properly cited. The work cannot be used commercially without permission from the journal. 


\title{
اثربخشى مدل ذهن آكاهى مبتنى بر ارتقاى عملكر ورزشى (MSPE) بر توجه، بر ناملريزى و عملكرد ورزشى جودو كاران نغريبه
}

\author{
ميثم شاه حسينى '، يرويز صباحى '، شاهرخ مكوند حسينى '، بهروز كل محمدى ' \\ ا. ا.كارشناسى ارشد روانشناسى، گروه روانشناسى، دانشخاه سمنان، سمنان، ايران.

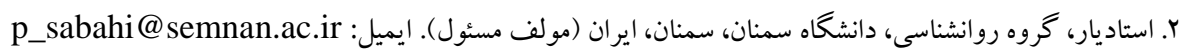 \\ r. r. دانشيار، كروه روانشناسى، دانشخاه سمنان، سمنان، ايران.

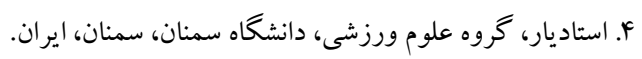

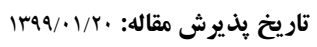

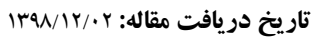

جكيده مقدمه: در ساليان اخير تمركز بر فرايندها و توانمندىهاى شناختى ورزشكاران مورد توجه بسيارى از روانشناسان و متخصصان علوم شناختى قرار گرفته است.

هدف: بر همين اساس هدف از مطالعه حاضر ارزيابى اثربخشى مدل ذهن آكاهى مبتنى بر ارتقاى عملكرد توجه، برنامهريزى و عملكرد ورزشى جودو كاران نخبه بود.

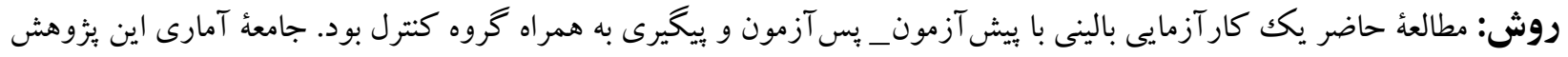

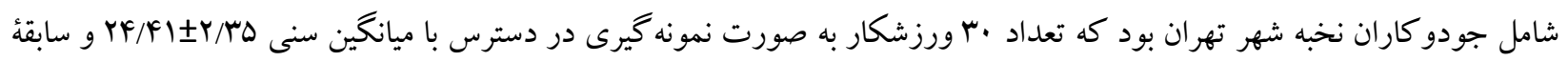

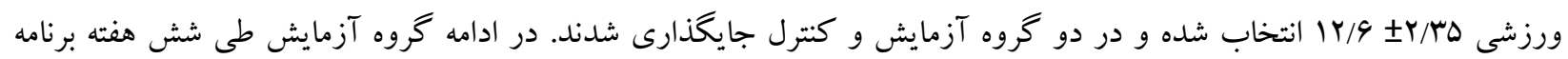

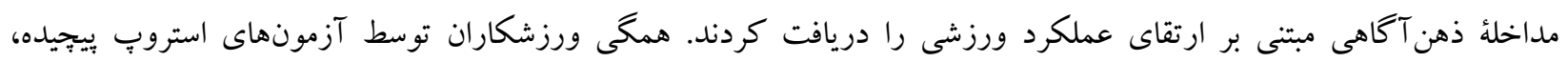

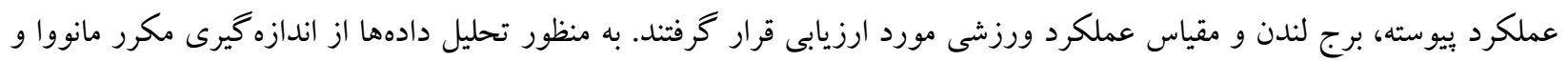
آنووا استفاده شد.

يافتها: يافتهاى يثزوهش حاضر نشان داد كه آموزش ذهن آكاهى مبتنى بر ارتقاى عملكرد ورزشى بهصورت معنادارى موجب بهبود

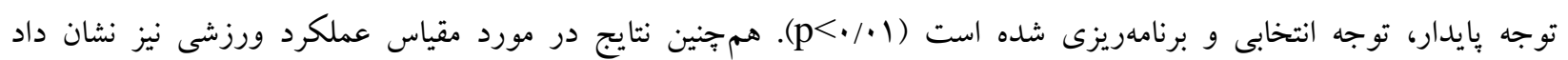

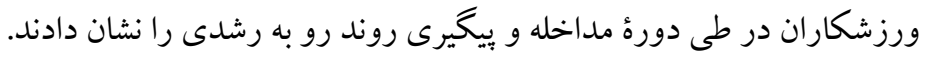

نتيجه كيرى: آموزش ذهن آكاهى مبتنى بر ارتقاى عملكرد ورزشى مى تواند در بهبود عملكرد شناختى و ورزشى مؤثر واقع شود و

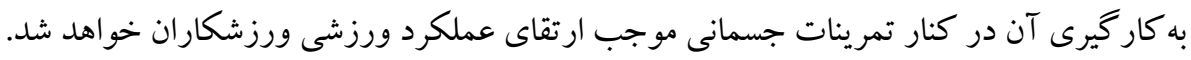
كليدوازهها: جودو كار ان، ذهن آكاهى، توجه، عملكرد ورزشى 
به اهداف خود دست يابد. وسبرگك و همكاران مقدمه

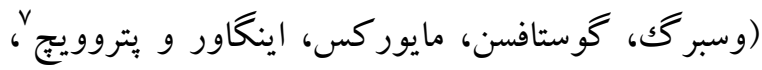

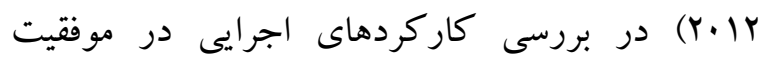
فوتباليست ها اشاره كردند كه كار كردهاى اجرايى از قبيل انواع توجه، حافظه كارى و حل مسئله بيشبينى كننده: قدرتمندى براى موفقيت ورزشكاران رشتهاى تويى لونى محسوب مىشود. توجه اين امكان را فراهم مىسازد كه فرد با تمركز يا انقطاع از يكك يديدهُ خاص و توجه به

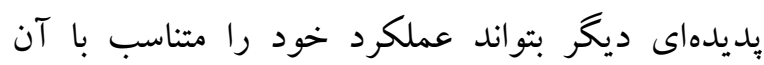
برنامهريزى كرده و بهترين تصميم را اتخاذ نمايد. برنامهريزى از جمله مهم ترين فرايندهاى عالى ذهن است كه بخش وسيعى از كاركردهاى اجرايى مغز را در

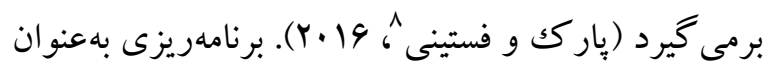
ظرفيت ايجاد و سازماندهى يك توالى لى از گامهاى ضرورى براى انجام رفتارهاى هدفمند تعريف مىشود

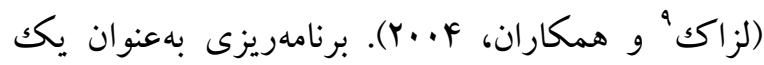
فرايند شناختى، توانايى طبقهبندى اهداف به اهداف فرعى در يكك توالى معين براى رسيدن به همه اهداف فرعى بهصورت يككبه يك است. ايجاد يك هدف،

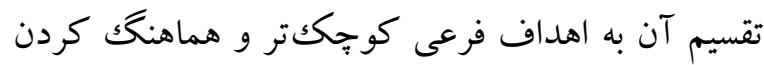
تمام اهداف فرعى، در نظر گرفتن تمام گامهاى ضرورى بر اساس برنامه و درنهايت تصميم گيرى و اجراى تمام كامها بهعنوان مهمترين مراحل برنامهريزى محسوب

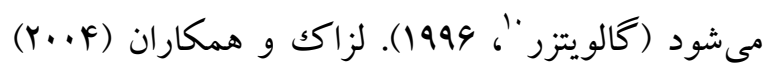
برنامهريزى را توانايى شناسايى و سازماندهى مراحل و عناصر مورد نياز براى انجام يكك قصد يا رسيدن به يكك هدف تعريف مىنمايند. ورزشكاران براى رسيدن به

7. Vestberg, Gustafson, Maurex, Ingvar \& Petrovic

${ }^{8}$ - Park, Festini

${ }^{9}$ - Lezak

${ }^{10}$ - Gollwitzer

1- Faubert \& Sidebottom

2- Etkin, Egner \& Kalisch

3 - Pourtois, Schettino, \& Vuilleumier

${ }^{4}$ - Myers, Hansen

5 - Pashler, Johnston, Ruthruff

${ }^{6}$ - Khanin 
كاهش استرس انجام داد، نتيجه اين مطالعه نشان داد

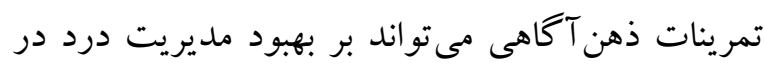
ورزش، تمركز، كاهش خستگى و هيجانات منفى مؤثر باشد (كابات زين، بيل و رايڤ، هـه (1). باين حال امروزه

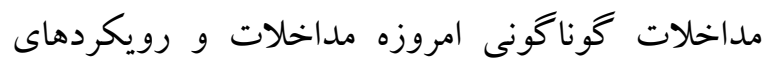
كوناگگ نى بر اساس ذهن آكاهى بر روى ورزشكاران ارائه

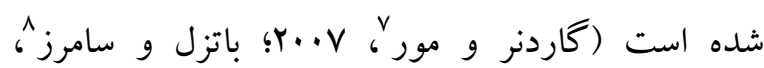

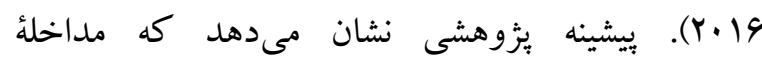

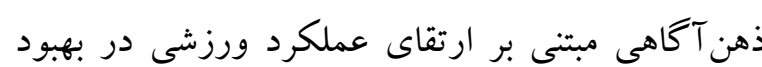
عملكرد ورزشى نقش مؤثرى داشته است (تامبسون،

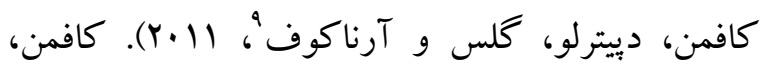

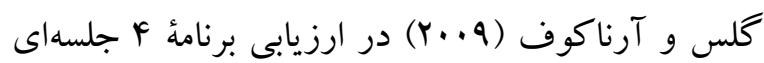
ذهن آكاهى مبتنى بر ارتقاى عملكرد ورزشى بر روى إس تجربه اوج و متغيرهاى روانشناختى (اضطراب صفتى، كمال گرايى، افكار مخرب، اعتمادبهنفس، ذهن آناهي) II كماندار و اب كلف باز دريافتند كه تغييرات برجستهاى در ابعاد متغيرهاى روانشناختى در طول تمرينات اتفاق مىافتد و بهتناسب سطح تجربه اوج ورزشكاران بين جلسه اول و جلسه آخر تفاوت بارزى را نشان مىدهد. مطالعات ديخرى نيز به نقش ذهن آكاهى مبتنى بر ارتقاى عملكرد ورزشى در كاهش اضطراب

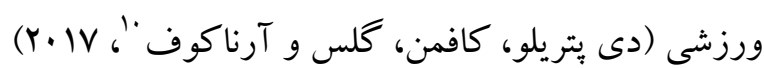

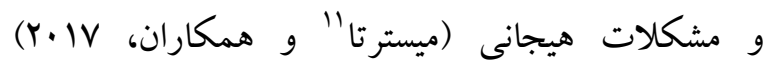
اشاره كردهاند. در ساليان اخير بررسى فرايندهاى عالى ذهن در راستاى به كار گيرى توانايى هاى بالقوهُ انسان موردتوجه بسيارى از علوم قرارگرفته است و حوزه روانشناسى ورزش نيز از

7. Gardner \& Moore

8 - Baltzell \& Summers

9- Thompson, Kaufman, De Petrillo, Glass \& Arnkoff

${ }^{10}$ - De Petrillo, Kaufman, Glass, \& Arnkoff

11- Mistretta
اهداف خود نيازمند برنامهريزى بهموقع مىباشند، ريلى و

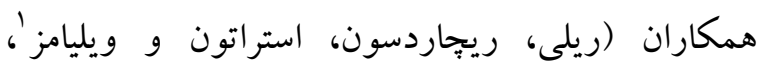
(Y...F معتقدند كه يك ورزشكار موفق، ورزشكارى است كه توانايىهاى شناختى بالايى از قبيل برنامهريزى، توجه فضايى، حافظه كارى و ذهنى سازى را در خود برورش دهد و قادر باشد كه بهسرعت خود را با شرايط

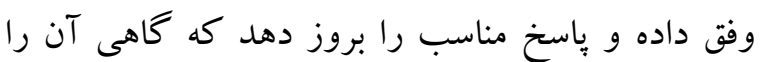
هوش مسابقهاى لقب مىدهند. وربرگك و همكاران

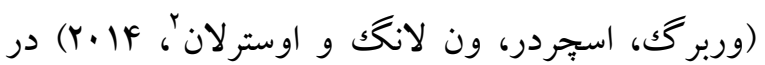
بررسى عملكردهاى شناختى ورزشكاران نخبه در مقايسه با ورزشكاران عادى در رشته فوتبال دريافتند كه اين ورزشكاران از عملكرد شناخت بالاترى از قبيل كوشبهزنكى، توجه و برنامهريزى برخوردار مىباشند.

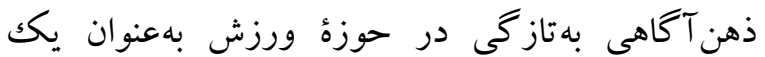
استراتزى و راهبردى باقابليت ارتقاى عملكرد شناختى مطرحشده است (بولماهر، بيرر، روتلين، فد و دوناس باّك

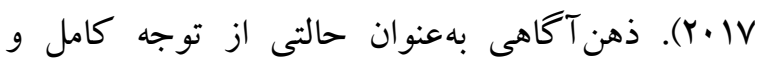
يذيرش تمامى تجرييات درونى و بيرونى، بلدون هيج قضاوتى در مورد اين تجربيات تعريف مىشود (كابات

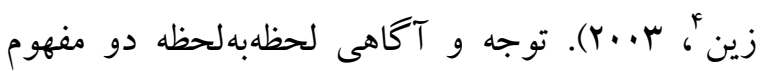
بنيادى در ذهن آكاهى است كه در بهبود توانايى

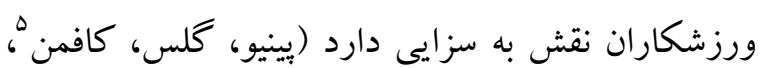

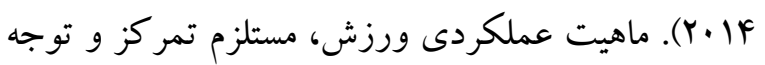
بيوسته بر روى نشانهاى مرتبط باهدف است (موران؛

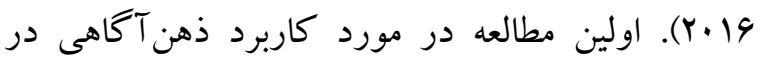
ورزش را جان كابات زين با عنوان ذهن آكاهى مبتنى بر درود دهن

\footnotetext{
1- Reilly, Richardson, Stratton \& Williams

2- Verburgh, Scherder, van Lange \& Oosterlaan

3 - Bühlmayer, Birrer, Röthlin, Faude, \& Donath

4- Kabat-Zinn

5 - Pineau, Glass \& Kaufman
}

${ }^{6}$ - Moran 
جودو كار نخبه بهصورت در دسترس براى اين بئوهش

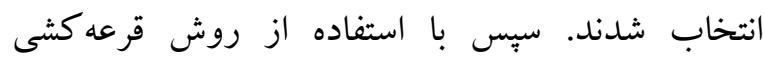

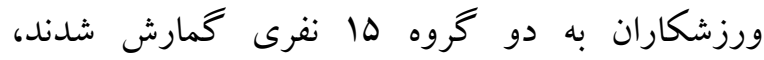
بهورى كه نيمى از ورزشكار ان مداخلهُ ذهن آكاهى مبتنى بر ارتقاى عملكرد ورزشى را دريافت كردند (D=1ه) و و مابقى افراد نيز در ليست انتظار قرار كرفتند. معيارهاى

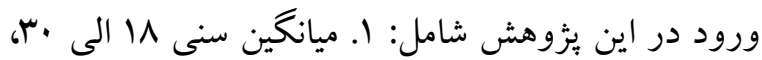
r. حداقل تحصيلات ديبلم، r. حداقل سه جلسه تمرين در هفته F. شركت بهصورت داوطلبانه ه. حداقل يكك سال سابقه ورزشى در رشتهُ جودو و معيارهاى خروج شامل: 1. بيش از دو جلسه غيبت در جلسات مداخله r. عدم رضايت براى شركت در مداخله س. تكميل ناقص آزمون

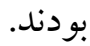
شيوه اجراى بزوهش بدينصورت بود كه با هماهنكى

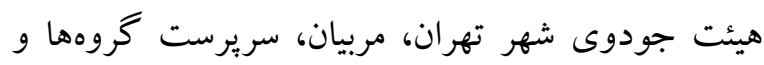
باشگاههاى ورزشى، فراخوانى براى شركت در مداخله ذهن آكاهى مبتنى بر ارتقاى عملكرد ورزشى اطلاعرسانى ورسى

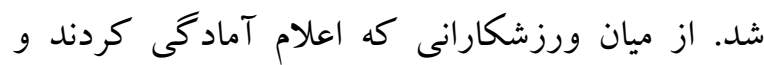
واجد ملاككهاى ورود يُزوهش بودند دعوت به عمل آورده شد تا پِ از تكميل فرم رضايت آكاهانه در مداخله شركت نمايند. در ادامه بـ إس از تخصيص ورزشكاران به دو گرووه آزمايش و كنترل، بيش آزمون در قالب آزمونهاى رايانهاى از ورزشكاران گُرفته شد. به منظور جلو گيرى از خستخى ورزشكاران در فرايند ارزيابى رايانهاى از روش اثر ترتيب به همراه زمانهاى استراحتى براى بازيابى و حفظ شرايط ايدئال

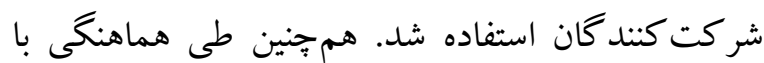

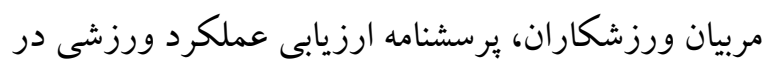
اختيار مربيان قرار كرفت و از آنها خواسته شد قبل از ورسئ
اين امر مستثنا نبوده است. متخصصان علوم ورزشى موفقيت ورزشى را حاصل تر كيبى از توانايىهاى جسمانى و ذهنى مىدانند و بسيارى از مربيان حرفهاى جهان نيز بر اين باورند كه دست كم بنجاهدرصد از موفقيت در يكى

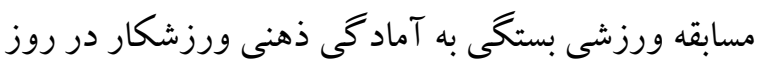

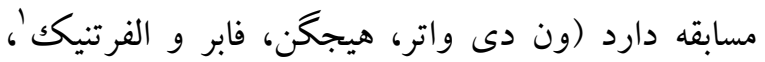

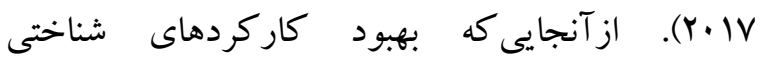
ورزشكاران روش جديدى در مديريت عملكرد ورزشى لهى محسوب شود، محققان در تكايو براى دستيابى به مداخلهاى كارآمد درصدند تا بدينوسيله توانمندى ورزشكاران را براى حضور در عرصههاى بين المللى بهبود ببخشند. در همين راستا با توجه به نقش تأثير گذار ذهن آكاهى در ابعاد متنوع روانشناختى، به نظر مىرسد آموزش ذهن آكاهى به ورزشكاران مى تواند نقش مؤثرى را در بهبود كاركردهاى شناختى (جسيا، كالاتى و

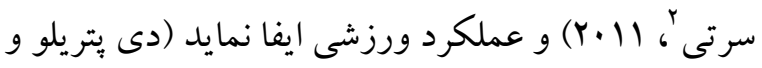

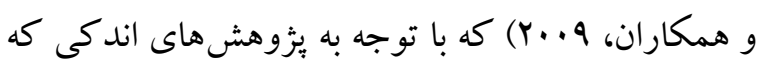
در اين حوزه صورت گرفته است نيازمند يثزوهشهاى منسجمترى است؛ بنابراين هدف از ئزوهش حاضر اثربخشى مدل ذهن آكاهى مبتنى بر ارتقاى عملكرد ورزشى بر توجه، برنامهريزى و عملكرد ورزشى جودو كاران نخبه بود.

روش مطالعه حاضر يكك كار آزمايى بالينى از نوع ييش آزمون_

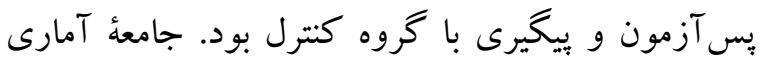

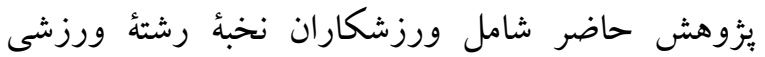
جودو در شهر تهران در سال وهسا بود كه تعداد .

1- Van de Water, Huijgen, Faber \& Elferink-Gemser

${ }^{2}$ - Chiesa, Calati \& Serretti 
استروبٍ (هب91) بهنظور اندازه گيرى توجه انتخابى، مهار و انعطاف يذيرى شناختى ساخته شد (جانگگ' و همكاران،

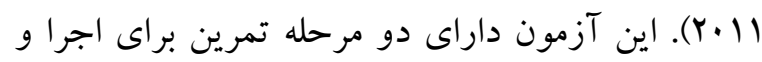
مرحله اجراى اصلى آزمون است كه بهصورت نسخه

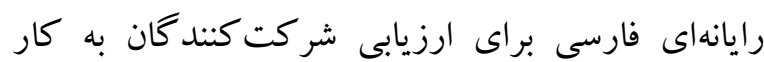

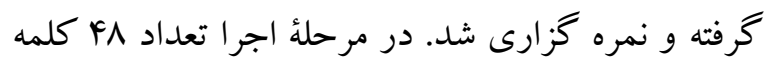

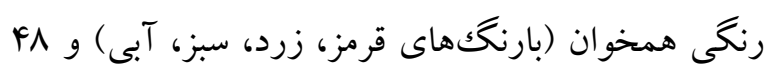
كلمه رنكى ناهمخوان (بهعنوانمثال كلمه قرمز كه بارنگك سبز نشان داده مىشود) ارائه مىشود. سبِ زمان واكنش به محر كههاى همخوان، ناهمخوان و نمره تداخل بهصورت ميلىثانيه ارزيابى مىشود. جانگك و همكاران (Y.11) با استفاده از آلفاى كرونباخ همسانى درونى اين

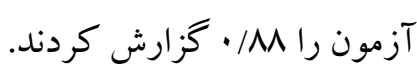
آزمون عملكرد بيوسته: بهمنظور بررسى توجه يايدار از

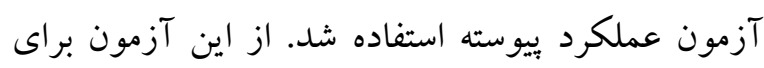
ارزيابى توجه يايدار و مداوم و نقايص بازدارى استفاده

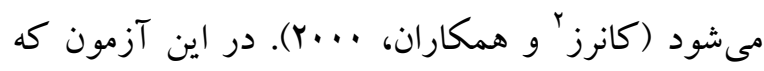

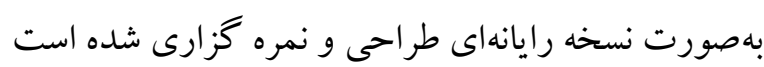
يكك سرى اعداد بافاصلههايى معين ظاهرشده و آزمودنى بايد با مشاهده اعداد موردنظر هرجه كليد مربوطه را بر روى صفحه كليد رايانه فشار دهد. محرك هدف هند هنباً

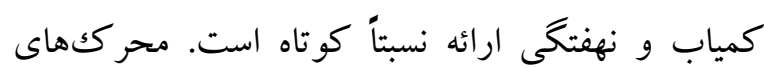
ارائهده ·r درصد هدف و •N درصد غير هدف بود. متغيرهاى موردسنجش در اين آزمون عبارتاند از تعداد ياسخ صحيح و زمان واكنش (ميانكين زمان واكنش ياسخهاى صحيح در برابر محركك بر اساس هزارم ثانيه) بود. به منظور بررسى بايايى اين ابزار كانرز و همكاران

1. Chang

${ }^{2}$ - Conners
اجراى مداخله براى هر ورزشكار فرم حاضر را تكميل

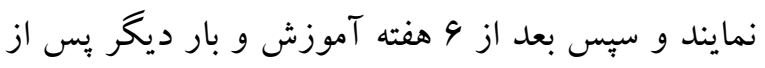

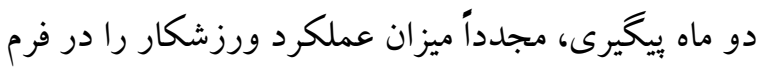
مذكور تكميل نمايند. دورة آموزشى ذهن آكاهى مبتنى بر ارتقاى عملكرد ورزشى در سالن كنفرانس يكى از باشگاههاى ورزشى طى شش هفته بركزار شد. بـ بس از اتمام دوره آموزشى ذهن آكاهى مبتنى بر ارتقاى عملكرد

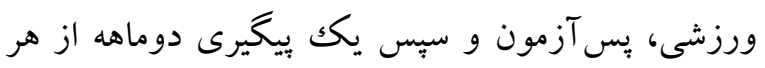

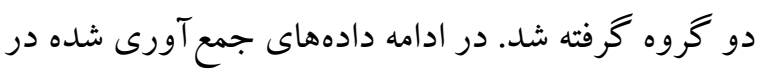
دو سطح آمار توصيفى و آمار استنباطى مورد تحليل قرار كرفتند. در سطح توصيفى متغيرهاى توجه انتخابى توسط استروبٍ تست (ياسخ همخوان، پِاسخ ناهمخوان و نمره تداخل) توجه يايدار توسط آزمون عملكرد ييوسته (نمره صحيح، زمان واكنش)، برنامهريزى توسط آزمون برج لندن (نمره صحيح، زمان شروع، زمان كل آزمايش) و و عملكرد در سه سطح در دو گروه آزمايش و كنترل ارزيابى شد؛ اما در سطح استنباطى براى بررسى اثرات بين كروهى و درونگروهى از اندازهگيرى مكرر مانووا و و آنووا استفاده شد. در ادامه تصحيح بونفرونى براى كاهش شانس خطاى نوع اول و تفاوت درون كروهى استفاده شد. يرسشنامه دموكرافيك: : براى دريافت اطلاعات

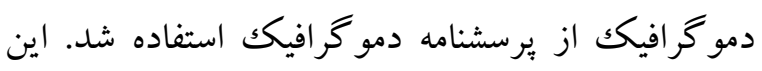
برسشنامه شامل اطلاعاتى از قبيل سن، جنس، تحصيلات، سابقه مصرف مواد نيروزا و سابقه ورزشى بود. آزمون استروب: بهمنظور بررسى توجه انتخابى از آزمون

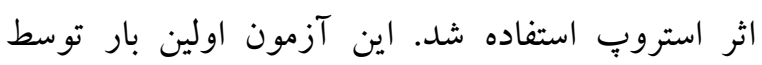




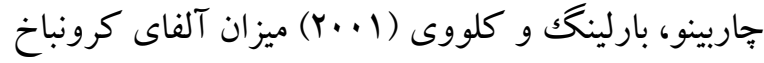

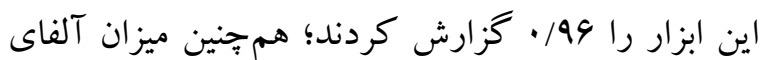
بررسى شده در اين بروهش نيز •9/، به دست آمد كه نشان از همسانى درونى بالاى اين برسشنامه دارد.

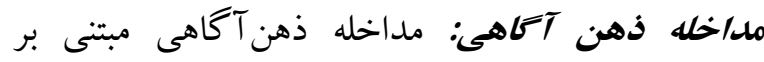
ارتقاى عملكرد ورزشى شامل شش جلسه آموزش ذهن آكاهى بهمنظور ارتقاى عملكرد ورزشكاران است

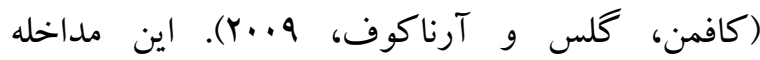
بر خرفتهشده از مداخلات كاباتزين و ويليام و تيزدل و ساير منابع مرتبط با ذهن آكاهى ورزشى بود. ذهن آكاهى مبتنى بر ارتقاى عملكرد ورزشى از ساختارى برخوردار

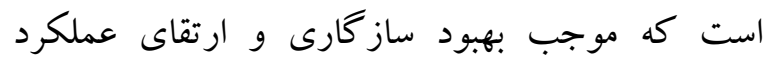
ورزشكاران مىشود. اين مداخله شامل 9 جلسه تمرينات ذهن آكاهى از قبيل وارسى بدنى، تنفس سهدقيقهاى، فعاليتهاى ورزشى با ذهن آكاهى و ... است. در اين مداخله به ورزشكاران آموزش داده مىشود كه جطور خود آكاهى و يذيرش را يرورش دهند و از ذهن آكاهى در محيط ورزشى و زندگى روزانه براى ارتقاى عملكرد استفاده نمايند. ورزشكاران در طى هفته صداهاى ضبطشده از تمرينهاى ذهن آكاهى به همراه انجام فعاليت با ذهن آكاهى را تمرين مىنمايند.

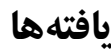
در اين بزّوهش تعداد ·م ورزشكار رشتهُ ورزشى جودو

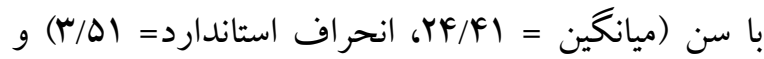
سابقهُ ورزشى (ميانخين= Y/9/4، انحر اف استاندارد هـ/Y) در دو گروه آزمايش و كنترل قرار گرفتند. بررسى ويز گیىاى جمعيت شناختى در دو گروه آزمايش و ورو كنترل مورد بررسى قرار گرفت. در كروه آزمايش ل
(Y...)

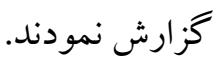

آزمون برج لنلان: بهمنظور بررسى برنامهريزى شناختى در ورزشكاران از آزمون برج لندن استفاده شد. اين آزمون اولين بار توسط شاليس (YAM) ساخته شد تا توانايى برنامهريزى را در بيماران با صدمه لوب فرونتال بسنجد. در اين آزمون از فرد خواسته مىشود تا مجموعهاى از مهرههاى رنكى سوار شده بر سه ميله عمودى را براى جور شدن با يكك هدف مشخص جابجا

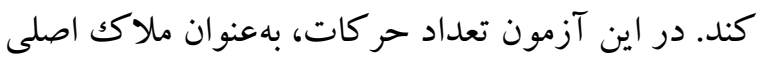
نمره دهى عملكرد محسوب مى شود و زمان برنامهريزى، مدتزمان لمس حلقه اول و زمان نيز مىتواند بهعنوان

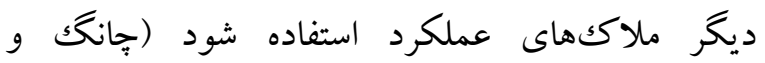

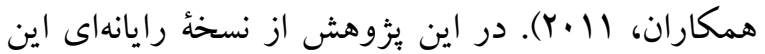

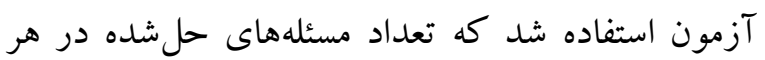
نوبت، زمان تأخير، زمان آزمايش بهصورت زمان واكنش بر اساس ثانيه (RTs) و يكك نمره كل براى حل مسائل محاسبه مىشود. اين آزمون داراى روايى مناسبى در سنجش، برنامهريزى و سازماندهى است و بين نتايج اين

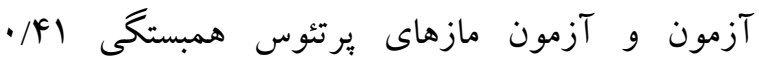
كزارششده است؛ اعتبار اين آزمون نيز موردقبول V9/.

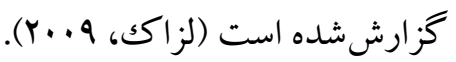
برسشنامه عملكرد وززشي: با استفاده از برسشنامه عملكرد

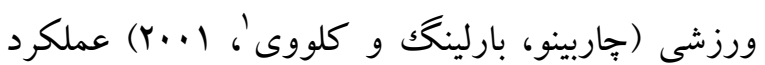
ورزشكاران توسط مربيان در طول تمرينات و مسابقات تخمين زده مىشود. مربيان ميزان ارتقاى عملكرد ورزشكاران خود را در يكك مقياس ليكرت ا(كمترين) تا ها (بيشترين) در طول تمرينات و مسابقات ثبت مى كنند.

\footnotetext{
1. Charbonneau, Barling \& Kelloway
} 
مجرد و | (\%/494) ورزشكار متأهل بود. در جدول 1 ا.

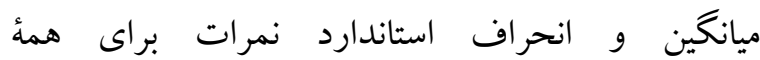
اندازه گيرىهاى صورت گرفته ارائهده است. جولكى و كشيدگى تمامى متغيرهاى بثزوهش بين Y كه قابل يذيرش بوده و حاكى از نرمال بودن دادهها دارد.

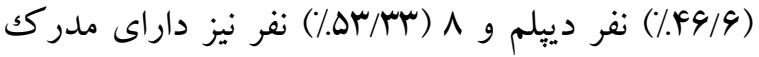
كارشناسى بودند، ميانگين ساعت تمرين ورزشى آنها V/Y ساعت در هفته بود، هم جنين سا (4/9/1) ورزشكار مجرد و Y (سس/MI\%) نفر متأهل بودند. در گروه كنترل 4

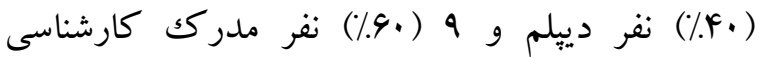
داشتند. ميانگين ساعت تمرينى ورزشكاران در گروه

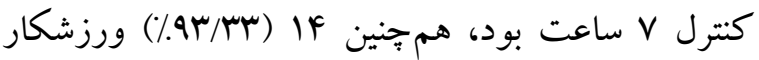

جدول شماره ا ميانكين و انحر اف استاندارد متغيرهاى ثئوهش در سه سطح

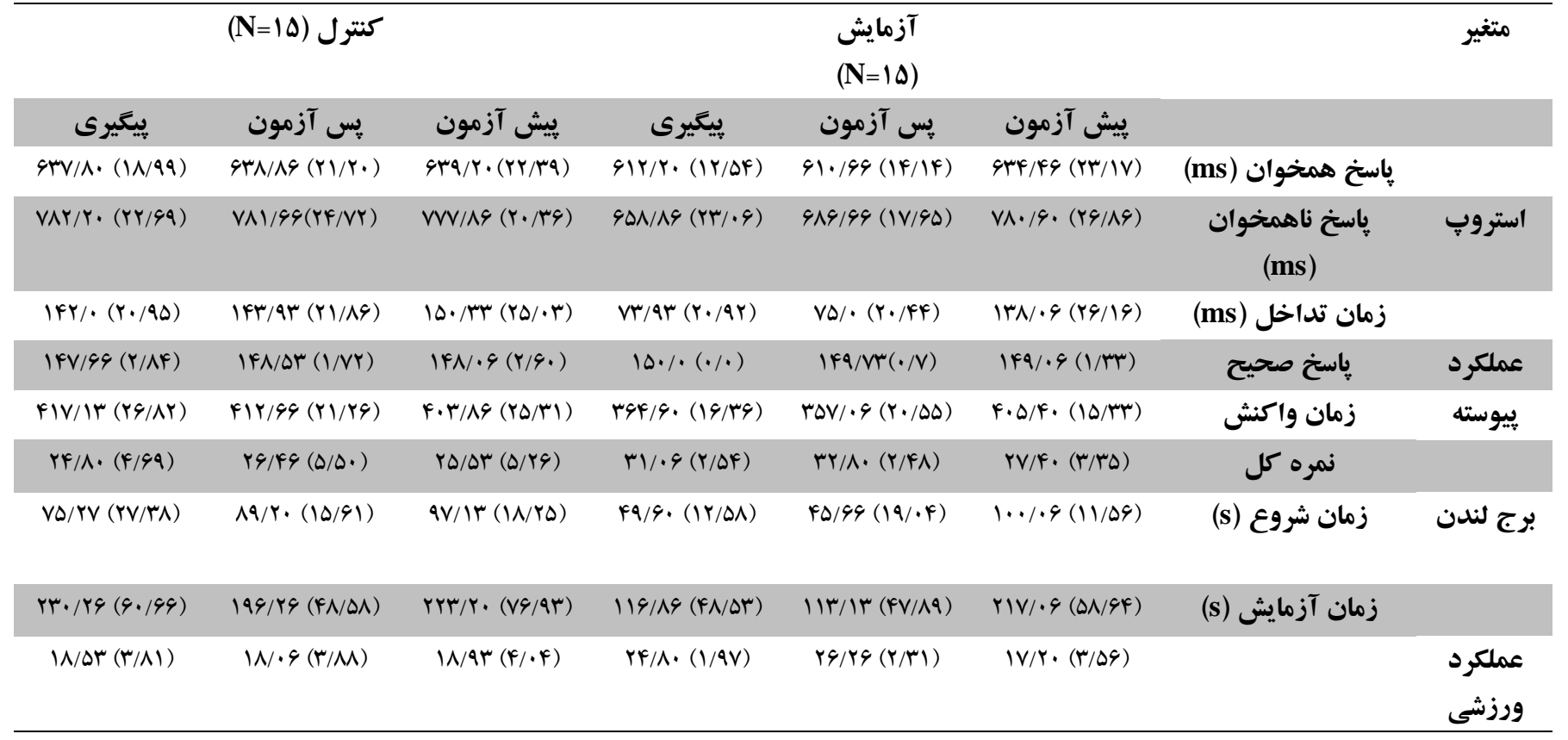

مشاهدهشده متغيرهاى وابسته در بين گروههاى مختلف در

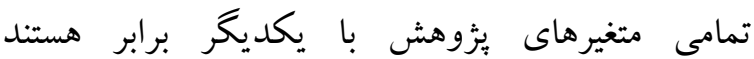

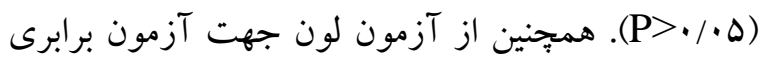
واريانسهاى خطا در مراحل مختلف آزمايش استفاده شد. نتايج آزمون لون به ترتيب در تمامى مؤلفههاى يثزوهش نشان از عدم معنادارى بود كه حاكى از يكسانى واريانسهاى خطا در مراحل مختلف آزمايش دارد

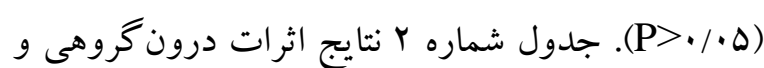

ازآنجايى كه يزوهش حاضر شامل سه مرحله اندازه كيرى (ييش آزمون، يس آزمون و بيگيرى) و متغيرهاى وابسته (توجه پيايدار و گزينشى، برنامهريزى، عملكرد ورزشى)

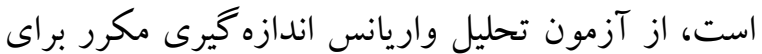
تحليل دادهها استفاده شد. بيش از اجراى آزمون تحليل

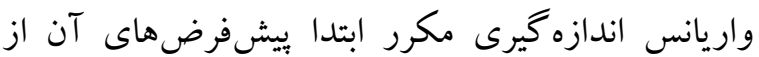
قبيل آزمون ام باكس و آزمون لون موردبررسى قرار كرفت نتايج آزمون ام باكس نشان داد كه ماتريس 
بين گروهى با آزمون اندازه گيرى مكرر تر كيبى به همراه

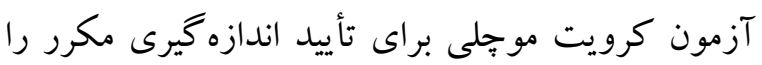

\begin{tabular}{|c|c|c|c|c|}
\hline زمان * كروه & تروه & زمان & & متغير \\
\hline $1 \cdot / r 9 *$ & $Q / \Delta F *$ & $\mid r / r V_{*}^{*}$ & ياسخ همخوان (ms) & \\
\hline $119 / 9 F_{*}$ & Vq/1. $*$ & $Q \mathrm{~V} / \mathrm{rV}$ * & ياسخ ناهمخوان (ms) & استروڤ \\
\hline$r N / \Delta \Delta *$ & $\Delta r / 19 *$ & $F N / 10 *$ & زمان تداخل (ms) & \\
\hline$V / \Delta Q_{*}$ & $G / \Delta F *$ & $1 / r \mu$ & ياسخ صحيح & عملكرد \\
\hline$\Delta \Delta / r \mid *$ & $1 \Delta / r \cdot *$ & $\mid F / M Y *$ & زمان واكنش & بيوسته \\
\hline$V / \Delta Y_{*}$ & $\mid V / / \Delta *$ & $\mu / \mu F$ & نمره كل & \\
\hline$V / \Delta r_{*}$ & $19 / \cdot \Delta *$ & $9 \Delta / \mu F_{*}$ & زمان شروع (s) & برج لندن \\
\hline$\Lambda / \vee 9^{*}$ & $r F / r Y *$ & $\mid r / \Delta \Lambda *$ & زمان آزمايش (s) & \\
\hline$\wedge 9 / \Delta 9 *$ & $\mid r / A F_{*}$ & $V \cdot / I F * *$ & & عملكرد ورزشى \\
\hline
\end{tabular}

آزمون كرويت موجلى براى بِاسخ ناهمخوان نشان داد كه

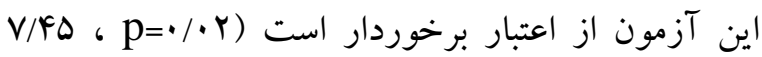
( $X^{2}=$

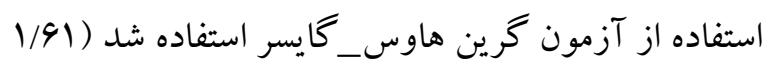

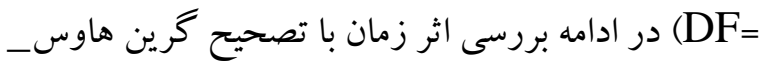
كايسر نشان داد كه تفاوت معنادارى ميان سه سطح از

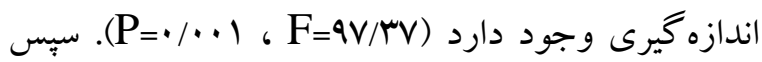
تصحيح بونفرونى براى تفاوت بين سه سطح اندازه گيرى نشان داد كه بين بيش آزمون با بس آزمون (ه •/P> (P) و و

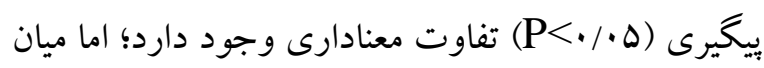
يس آزمون و بيگيرى هيج تفاوت معنادارى وجود ندارد (P=1/•) تفاوت معنادارى در اثر تر كيبى وجود دارد (F=19/9F ، و مداخله موجب كاهش زمان واكنش بِاسخ ناهمخوان در شر كت كنند كان شده است. آزمون كرويت موجلى براى متغير نمره تداخل نشان داد

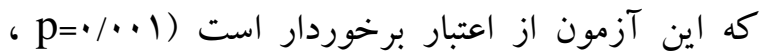

استروب تست. آزمون كرويت موجلى براى متغير پِاسخ همخوان نشان داد كه اين آزمون از اعتبار برخوردار است

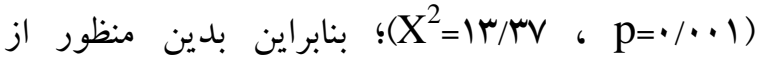
تصحيح درجهُ آزادى با استفاده از آزمون گرين هاوس - بـاين كايسر استفاده شد ( (DF=|/F) در ادامه بررسى اثر زمان با تصحيح گرين هاوس_گايسر نشان داد كه تفاوت معنادارى ميان سه سطح از اندازهگيرى وجود دارد

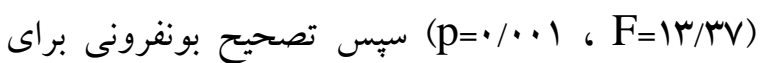
تفاوت بين سه سطح اندازهگيرى نشان داد كه بين

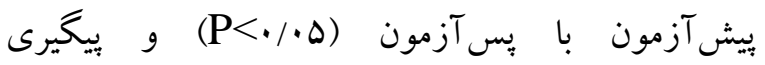
تفاوت معنادارى وجود دارد؛ اما ميان يس آزمون و بيگيگى هيج تفاوت معنادارى وجود ندارد

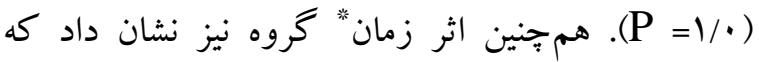

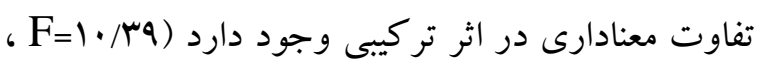
r./ ) و مداخله موجب كاهش زمان واكنش به بِاسخ همخو ان را در شر كت كنند كان شده است. 


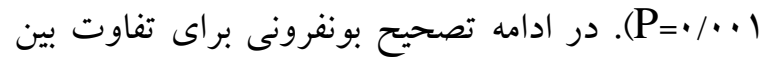

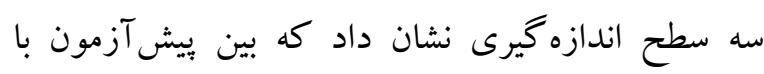

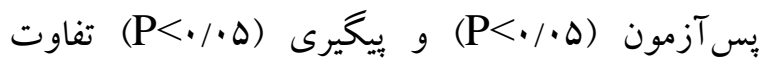
معنادارى وجود دارد؛ اما ميان بس بسآزمون و بيگيرى

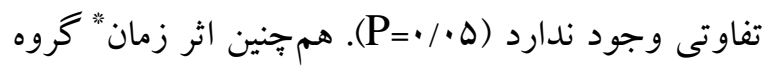
نيز نشان داد كه تفاوت معنادارى در اثر تركيبى وجود

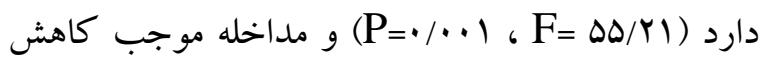
زمان بِاسخ در شركت كنند كان شده است. برج لندن. آزمون كرويت موجلى براى متغير نمره كل

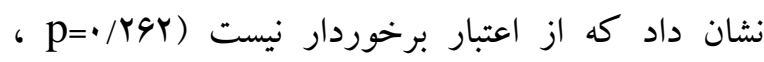
(X $X^{2}=r / 9 \Lambda$ زمان نشان داد كه از تفاوت معنادارى بيروى نمى كند (P=•/•V ، F=r/MF)

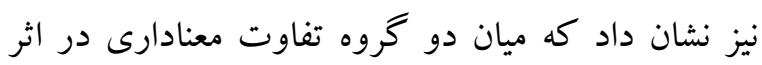

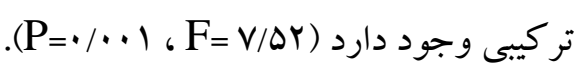
آزمون كرويت موجلى براى متغير زمان شروع نشان داد

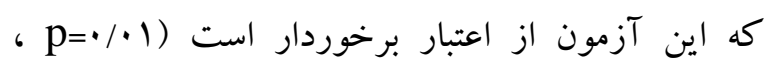
(X $X^{2}=\Lambda / \Lambda F$ با استفاده از آزمون گرين هاوس_كايسر استفاده گرديد در ادامه بررسى اثر زمان با تصحيح كرين (DF=1/ه4)

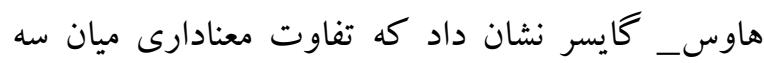

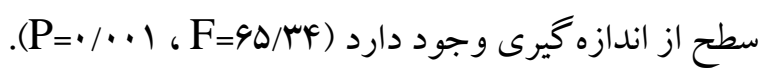
در ادامه تصحيح بونفرونى براى تفاوت بين سه سطح

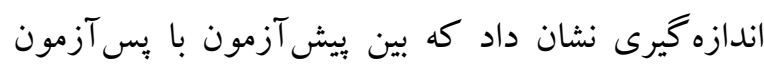

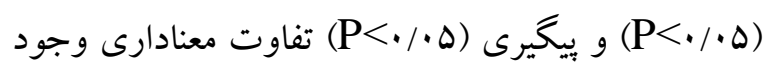
دارد ؛اما ميان بِ آزمون و بيگيرى تفاوتى وجود ندارد

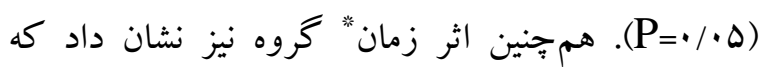

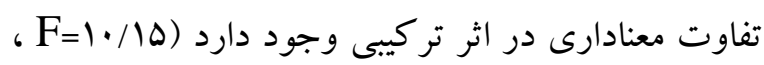

(X) آزادى با استفاده از آزمون گرين هاس_كايسر استفاده

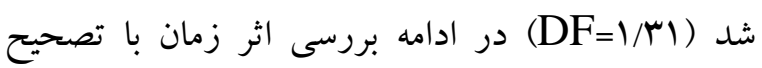
كرين هاوس_ گايسر نشان داد كه تفاوت معنادارى ميان

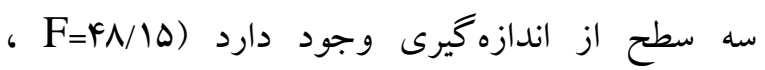
|

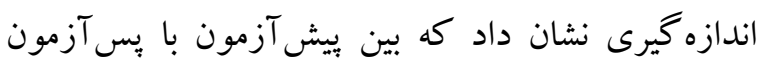

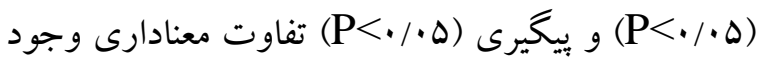
دارد؛ اما ميان بس آزمون و بيخيرى هيج تفاوت معنادارى

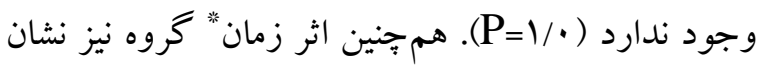
داد كه تفاوت معنادارى در اثر تركيبى وجود دارد ( $(\mathrm{P}=\cdot /$ م مداخله موجب كاهش نمره تداخل شده است. عملكرد بيوسته. آزمون كرويت موجلى براى متغير نمره صحيح نشان داد كه از اعتبار برخوردار نيست (V) (r/.•

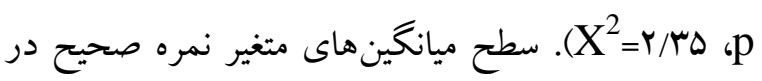

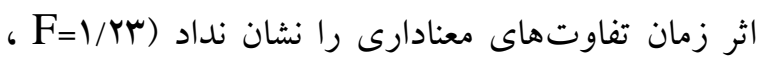

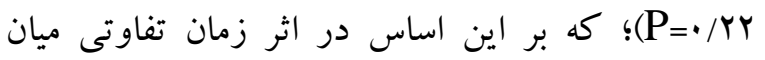

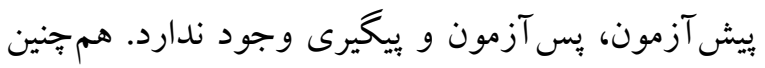

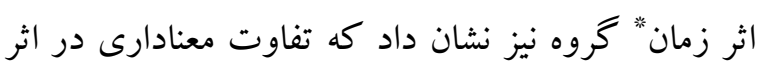

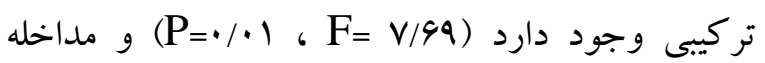
موجب بهبود كسب نمره صحيح در آزمون شده است. آزمون كرويت موجلى براى متغير زمان بِاسخ نشان داد

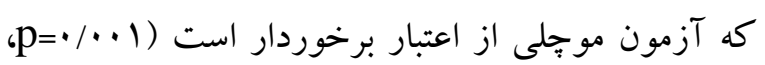

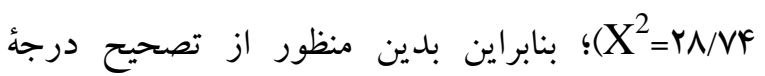
آزادى با استفاده از آزمون گرين هاوس_كايسر استفاده

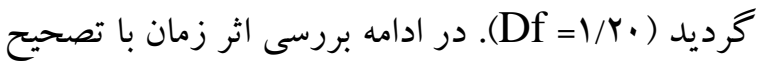
كرين هاوس_ كايسر نشان داد كه تفاوت معنادارى ميان

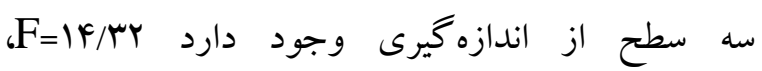


يس آزمون و يِيَيرى تفاوت معنادارى ايجاد نشده است (P=•/r)

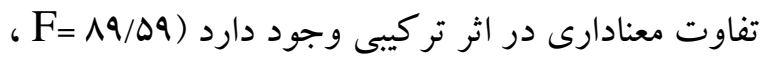

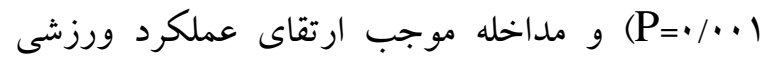
شر كت كنند كان شده است.

بحث در اين بثروهش اثر آموزش ذهن آكاهى مبتى بر ارتقاى

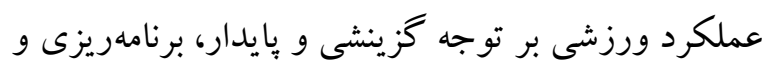
عملكرد ورزشى جودو كاران موردبررسى قرار كرفت. نتايج يزوهش حاضر نشان داد آموزش ذهن آكاهى مبتنى بر ارتقاى عملكرد ورزشى موجب بهبود توجه گزينشى، توجه پيايدار، برنامهريزى و درنهايت بهبود عملكرد جودو كاران در گروه آزمايش به نسبت گرووه كنترلشده است. بدين منظور براى دستيابى به بينش مناسب از نتايج،

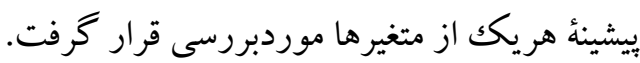
نتايج بثوهش حاضر در متغير توجه انتخابى نشان داد تمامى مؤلفه هاى توجه انتخابى از قبيل بِاسخ همخوان، ياسخ ناهمخوان، زمان تداخل از تفاوت معنادارى در ميان دو گروه برخوردار است كه يافتها حاكى از آن است، آموزش ذهن آكاهى مبتنى بر ارتقاى عملكرد ورزشى موجب بهبود متغير توجه انتخابى شده است. ورزشكاران طى تمرين و مسابقات در معرض محرككهاى مختلفى

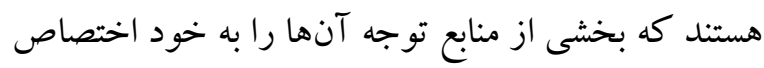
مىدهد؛ يكك ورزشكار رشته ورزشى جودو در معرض

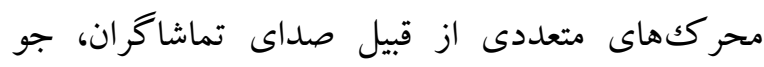
مسابقه، درخواست مربيان، داوران، حريف و... در طول يكك مسابقه ورزشى است و در كنار اين عوامل بيرونى، خواستهاى درونى شده و ميزان برانخيختخى ناشى از
و مداخله موجب كاهش زمان شروع در $(\mathrm{P}=\cdot /$ مان شر كت كنند كان شده است. آزمون كرويت موجّلى براى متغير زمان اجراى آزمايش نشان داد كه اين آزمون از اعتبار برخوردار است

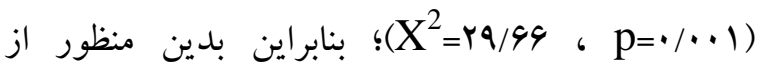
تصحيح درجهُ آزادى با استفاده از آزمون گرين

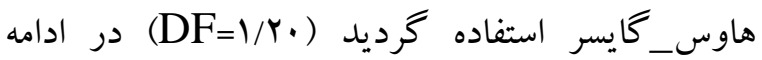
بررسى اثر زمان با تصحيح گرين هاوس_كايسر نشان داد كه تفاوت معنادارى ميان سه سطح از اندازه گيرى وجود

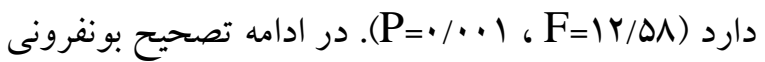
براى تفاوت بين سه سطح اندازه گيرى نشان داد كه بين

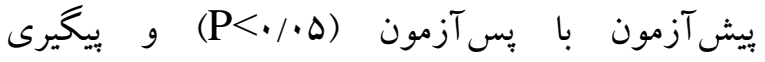
تفاوت معنادارى وجود دارد همجهنين ميان يس آزمون و بيگيرى نيز تفاوت معنادارى وجود دارد (P=•/・V) ت F= N/V9 ( تفاوت معنادارى در اثر تركيبى وجود دارد آ. و و مداخله موجب كاهش زمان اجراى آزمايش در شر كت كنند كان شده است. عملكرد ورزشى. آزمون كرويت موجِلى براى متغير عملكرد ورزشى نشان داد كه اين آزمون از اعتبار

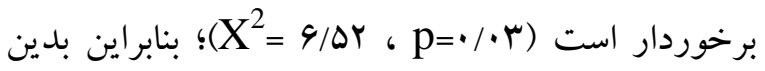

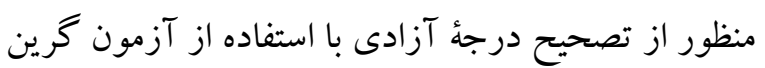

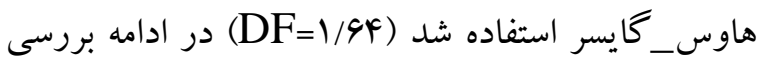
اثر زمان با تصحيح كرين هاوس- كايسر نشان داد كه تفاوت معنادارى ميان سه سطح از اندازه گيرى وجود دارد (P=•/・1 ، F=V•/lF) تفاوت بين سه سطح اندازهگيرى نشان داد كه بين

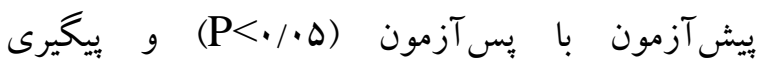
(P<•/ه) 
سهولت اجرا، عملى بودن و بهبود ارتقاى عملكرد ورزشى همخى ازجمله مزيتهايى بود كه اين امكان را در اختيار ورزشكاران قرار مىداد با اشتياق بيشترى تمرين و آموزش ذهن آكاهى را بيخيرى نمايند. مى توان مكانيسم عمل اثربخشى آموزش ذهن آكاهى مبتنى بر ارتقاى عملكرد ورزشى بر روى توجه پايدار را به كمكك نظريه رديابى علامت در جهار حالت (مثبت صادق، مثبت كاذب، منفى كاذب و منفى صادق) تبيين كرد

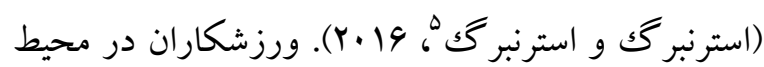
مسابقه و تمرين برانكيختخى و اضطرابهاى گوناگونى تجربه مى كنند كه موجب افزايش كوشبهزنكى آنان مىشود. ورزشكاران در حالت گُشبهزنكى با ريسك كمترى به محرككهاى هدف كه از طرف حريف ظاهر مىشود بِاسخ مىدهد (بهطور مثال در رشته جودو واكنشهاى لحظهاى حريف خود رادر نظر نمى گيرد)؛ و ورهي بدينوسيله لحظههاى حياتى را براى واكنش مناسب از

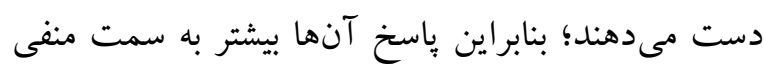
كاذب مىرود. ذهن آكاهى با تأثير مثبتى كه بر روى كنترل توجه، بايدارى بر روى محرك و ارتقاى رديابى

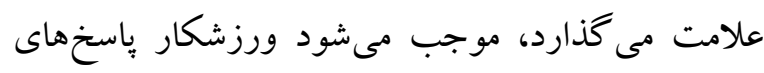
مثبت صادق بيشترى به واكنشهاى حريف خود در حين

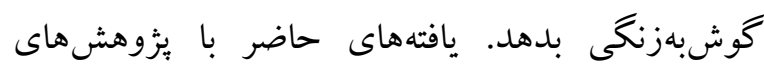

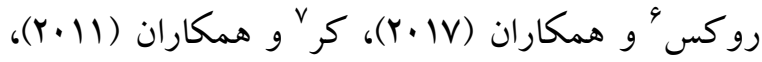

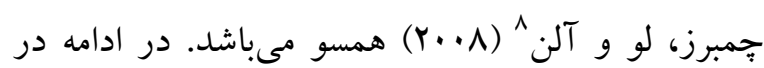
جهت يافتهاى ناهمسو با بُزوهش حاضر مىتوان به

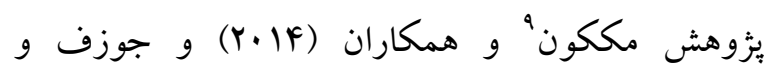

5 - Sternberg, Sternberg

${ }^{6}$ - Rooks

7- Kerr

8 - Chambers, Lo, \& Allen

9 - MacCoon

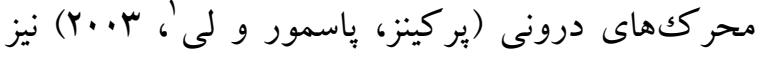
مى تواند توجه ورزشكار را تحت تأثير قرار دهد؛ بنابراين نيازمند آن است توجه خود را در لحظه به مسابقه و آنجه در جريان است معطوف نمايد و از اين توانايى برخوردار باشد كه با قطع توجه از يكك محرك به يردازش محر كك

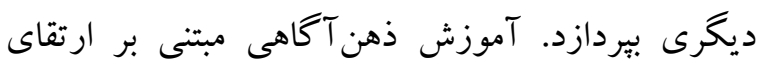
عملكرد ورزشى اين توانمندى را به ورزشكاران مى آموزد كه در طى تمرينات ذهن آكاهى توجه خود را به لحظه حال معطوف كرده و بدون نشخوار ذهنى

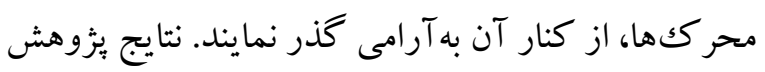

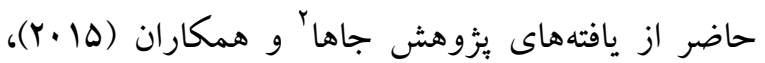

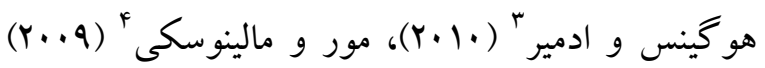
مبنى بر تأثير ذهن آكاهى بر توجه انتخابى حمايت مى كند. نتايج يُزوهش حاضر درزمينهُ توجه پِيدار نشان داد آموزش ذهن آكاهى موجب بهبود نمره صحيح و كاهش زمان ياسخ در جودو كاران گرووه آزمايش به نسبت گروه كنترلشده است. در تبيين يافتهاى بيزوهش حاضر مىتوان عنوان داشت، اغلب بيشينهاى بيزوهشى به اثربخشى آموزش ذهن آكاهى بر بهبود توجه اشاره

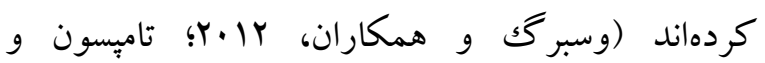
همكاران I|l(Y). توجه بايدار به ورزشكاران اين امكان را مىدهد تا ميزان تمركز ثابتى را در طى زمان مسابقه بر روى محر ككهاى هدف حفظ نمايند. مداخله ذهن آكاهى مبتى بر ارتقاى عملكرد ورزشى در اين بزوهش به

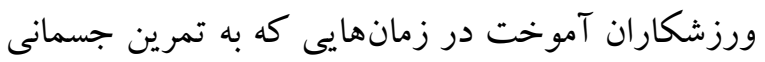
و تكنيكى اختصاصى جودو مى يرداختند از آموزشهاى ذهن آكاهى نيز بهرهمند شوند. دسترسى و ياد گيرى آسان،

\footnotetext{
1- Perkins-Ceccato, Passmore \& Lee

2. Jha

3 - Hodgins, \& Adair

4- Moore \& Malinowski
} 
محر ككهاى غيرضرورى، بهترين برنامهريزى و تصميم را در لحظه اتخاذ نمايند. يافتهاى اين ئزوهش از نتايج

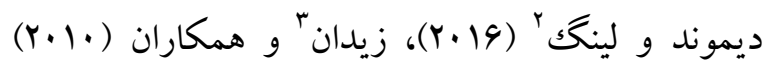
حمايت مى كند و يافته ناهمسويى مشاهده نشد. درنهايت بررسى عملكرد ورزشى جودو كاران در طول مداخله و بيخيرى نشان داد كه تفاوت معنادارى ميان دو برونى كروه مشخصشده است كه احتمال تأثير آموزش ذهن آكاهى مبتنى بر ارتقاى عملكرد ورزشى بر ارتقاى

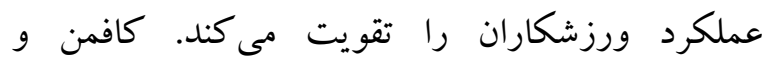
همكاران (q. (Y) در يكك مطالعه بر روى تيراندازان و

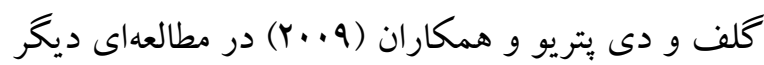
در طى f هفته آموزش ذهن آكًاهى بر روى عملكرد نشان دادند كه ذهن آكاهى در عملكرد تأثيرى بر روى عملكرد

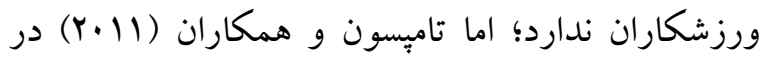
بررسى بيخيرى يككساله اين دو مطالعه به اين نتيجه دست يافتند تمرين ذهن آكاهى در عملكرد در طولانىمدت لئى موجب بهبود عملكرد دوند مان دو مسافت شده است. نتايج يثزوهش حاضر از نتايج تاميسون و همكاران (11) حمايت مى كند. يثزوهش حاضر با محدوديتهايى هم همراه بود. از مهمترين محدوديتهاى اين ئزوهش مىتوان به تعداد كم آزمودنىها اشاره كرد كه ميزان اثر مداخدمانه مىتواند تحت تأثير قرار دهد؛ همجنين انتخاب تنها ورزشكاران مرد جودو كار نيز مىتواند از ديخر محدوديتهاى اين ئزوهش باشد. همجنين محدوديت

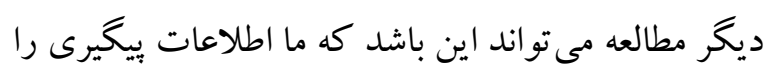
دو ماه يّ از مداخله جمع آورى كرديم كه بيشنهاد مىشود مطالعات آتى بهصورت ايدهآل اثرات بلندمدت

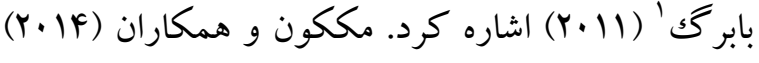
در يكك كار آزمايى بالينى بر روى سو نفر شركت كننده

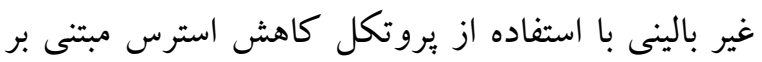

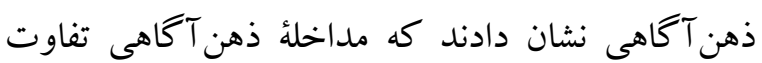
معنادارى ميان دو گروه آزمايش و كنترل در توجه يايدار ايجاد نكرد. در بررسى عدم همسويى نتايج مى توان عنوان داشت كه تفاوت در بروتكل و شركت كنند كان در يثوهش از مهمترين عامل اختلاف در يافتهاى اين دو يثزوهش مىتواند باشد. جوزف و بابركى (11) ئزوهش خود نشان دادند كه بعد از 1 هفته آموزش ذهن آكاهى بر روى ورزشكاران تفاوتى ميان كروه آزمايش و كنترل مشاهده نشد. اين تفاوت در نتايج مىتواند ناشى از مشكل در روش شناسى اين بثوهش يا استفاده از ابزار اندازه گيرى متفاوت باشد. نتايج بثوهش حاضر در متغير برنامهريزى با استفاده از آزمون برج لندن نشان داد كه تمامى مؤلفهاى برنامهريزى تفاوت معنادارى را در ميان دو كروه نشان مىدهند و حاكى از آن دارد كه آموزش ذهن آكاهى مبتى بر ارتقاى عملكرد ورزشى موجب ارتقاى

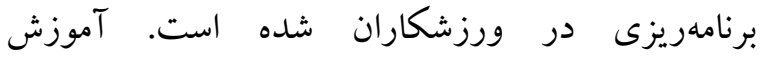

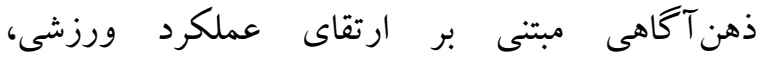
ورزشكاران را به اين سلاح مجهز مى كند كه با ارتقاى

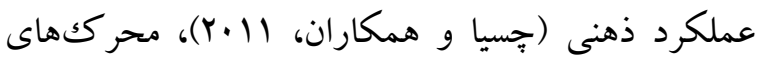
براكندهُ درونى و بيرونى را دستهبندى نموده و مطابق هدف اعمال خود تصميم گيرى نمايند. درواقع

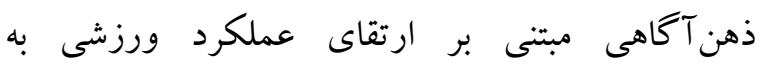
ورزشكاران در حين تمرين و مسابقه كمكك مى كند كه با قرار دادن ذهن خود در لحظه حال و با كنار كذاشتن 
نويسند كان مقاله حاضر بر خود لازم مىدانند، از تمامى

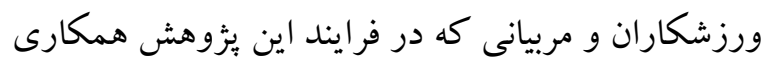
كردند تشكر و قدردانى به عمل آورده شود. اين مقاله مستخرج از ياياننامه كارشناسى ارشد است و هيج تضاد منافعى در آن وجود ندارد. اين يثوهش داراى كد اخلاق از كميته اخلاق دانشگاه علوم يزشكى سمنان به شماره (IR.SEMUMS.REC.1396.114) كار آزمايى بالينى ايران (20151020024625N5 (IRCT

\section{References}

Baltzell AL, \& Summers J. (2016). The future of mindfulness and performance across disciplines. In A.L. Baltzell (Ed.), Mindfulness and performance (pp. 515-541). New York: Cambridge University Press.

Bühlmayer L, Birrer D, Röthlin P, Faude O, \& Donath L. (2017). Effects of mindfulness practice on performance-relevant parameters and performance outcomes in sports: A metaanalytical review. Sports Medicine, 47(11), 2309-2321.

Chambers R, Lo BCY, \& Allen NB. (2008). The impact of intensive mindfulness training on attentional control, cognitive style, and affect. Cognitive therapy and research, 32(3), 303322.

Chang YK, Tsai CL, Huang CC, Wang CC, \& Chu IH. (2014). Effects of acute resistance exercise on cognition in late middle-aged adults: general or specific cognitive improvement? Journal of Science and Medicine in Sport, 17(1), 51-55.

Chang YK, Tsai CL, Hung TM, So EC, Chen FT, \& Etnier JL. (2011). Effects of acute exercise on executive function: a study with a Tower of London Task. Joumal of Sport and Exercise Psychology, 33(6), 847-865.

Charbonneau D, Barling J, \& Kelloway EK. (2001). Transformational leadership and sports
مداخله را بررسى نمايند. به نظر مىرسد مطالعات بعدى بايد بر روى اثرات اين مداخله بر ساير رشتههاى ورزشى بهخصوص رشته هاى تيمى، مقايسه با ساير مداخلات ذهن آكاهى، تفاوت مردان و زنان متمر كز شوند. مطالعات بعدى مىتوانند مداخلهُ ذهن آكاهى مبتنى بر ارتقاى عملكرد ورزشى را در ورزشكاران نخبه اجرا نمايند جراكه در توانمندى اين افراد براى شركت در مسابقات بين المللى مىتواند مؤثر باشد. بيشنهاد مىشود محققان بعدى مداخله ذهن آكاهى را در طى جلسات بيشتر و با زمانهاى كمتر براى ورزشكاران اجرا نمايند جراكه بيشينه يزوهشى كاربرد اين روش را مناسبتر نشان داده

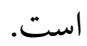

\section{نتيجه كيرى}

اين يزوهش براى اولين بار اثر رويكرد ذهن آكًاهى مبتنى

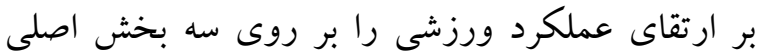
هيجانات، شناخت ها و عملكرد مورد بررسى قرارداد و درمجموع نتايج يُوهش حاضر نشان داد كه آموزش ذهن آكاهى مبتنى بر ارتقاى عملكرد ورزشى نقش مؤثرى

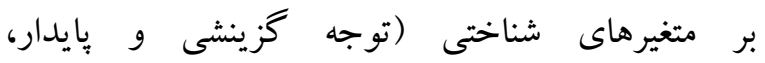
برنامهريزى)، هيجانى (يردازش هيجانى) و درنهايت عملكرد ورزشكاران ايفا مىنمايد؛ بنابر اين مىتوان نتيجه كرفت مداخلهُ ذهن آكاهى مبتنى بر ارتقاى عملكرد ورزشى از كارايى مناسبى در بهبود شاخصهاى روانى و بهمراتب تأثير آن بر بهبود عملكرد ورزشى برخوردار است و مى تواند در كنار تمرينات جسمانى بهعنوان مكمل | استفاده گردد.

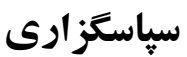


performance: the mediating role of intrinsic motivation 1. Journal of applied social psychology, 31(7), 1521-1534.

Chiesa A, Calati R, \& Serretti A. (2011). Does mindfulness training improve cognitive abilities? A systematic review of neuropsychological findings. Clinical psychology review, 31(3), 449-464.

Conners CK, Staff MHS, Connelly V, Campbell S, MacLean M, \& Bames J. (2000). Conners' continuous performance Test II (CPT II v. 5). Multi-Health Syst Inc, 29, 175-96.

De Petrillo LA, Kaufman KA, Glass CR, \& Amkoff DB. (2009). Mindfulness for long-distance runners: An open trial using Mindful Sport Performance Enhancement (MSPE). Journal of Clinical Sport Psychology, 3(4), 357-376.

Diamond A, \& Ling DS. (2016). Conclusions about interventions, programs, and approaches for improving executive functions that appear justified and those that, despite much hype, do not. Developmental cognitive neuroscience, $18,3448$.

Etkin A, Egner T, \& Kalisch R. (2011). Emotional processing in anterior cingulate and medial prefrontal cortex. Trends in cognitive sciences, 15(2), 85-93.

Faubert J, \& Sidebottom L. (2012). Perceptualcognitive training of athletes. Joumal of Clinical Sport Psychology, 6(1), 85-102.

Gardner FL, \& Moore ZE. (2007). The psychology of enhancing human performance: The mindfulness-acceptance-commitment (MAC) approach. Springer Publishing Company.

Gollwitzer PM. (1996). The volitional benefits of planning. In P. M. Gollwitzer \& J. A. Bargh (Eds.), The Psychology of Action: Linking Cognition and Motivation to Behavior (pp. 287-312). New York: Guilford Press.

Hodgins HS, \& Adair KC. (2010). Attentional processes and meditation. Consciousness and cognition, 19(4), 872-878.

Jha AP, Morrison AB, Dainer-Best J, Parker S, Rostrup N, \& Stanley EA. (2015). Minds "at attention": Mindfulness training curbs attentional lapses in military cohorts. PloS one, 10(2), e0116889.

Josefsson T, \& Broberg A. (2011). Meditators and nonmeditators on sustained and executive attentional performance. Mental Health, Religion \& Culture, 14(3), 291-309.

Kabat-Zinn J, Beall B, Rippe J. (1985). A systematic mental training program based on mindfulness meditation to optimize performance in collegiate and Olympic rowers. InPoster presented at the World Congress in Sport Psychology, Copenhagen.

Kabat-Zinn J. (2003). Mindfulness-based interventions in context: past, present, and future. Clinical psychology: Science and practice, 10(2), 144 156.

Kaufman KA, Glass CR, \& Arnkoff DB. (2009). Evaluation of Mindful Sport Performance Enhancement (MSPE): A new approach to promote flow in athletes. Joumal of Clinical Sport Psychology, 3(4), 334-356.

Kaufman KA, Glass CR, \& Arnkoff DB. (2009). Evaluation of Mindful Sport Performance Enhancement (MSPE): A new approach to promote flow in athletes. Joumal of Clinical Sport Psychology, 3(4), 334-356.

Kerr CE, Jones SR, Wan Q, Pritchett DL, Wasserman RH, Wexler A, ... \& Littenberg R. (2011). Effects of mindfulness meditation training on anticipatory alpha modulation in primary somatosensory cortex. Brain research bulletin, 85(3-4), 96-103.

Khanin IL. (2000). Emotions in sport. Human Kinetics.

Lezak MD, Howieson DB, Loring DW, Fischer JS. (2004). Neuropsychological assessment. Oxford University Press, USA.

MacCoon DG, MacLean KA, Davidson RJ, Saron CD, \& Lutz A. (2014). No sustained attention differences in a longitudinal randomized trial comparing mindfulness based stress reduction versus active control. PloS one, 9(6), e97551.

Mistretta EG, Glass CR, Spears CA, Perskaudas R, Kaufman KA, \& Hoyer D. (2017). Collegiate athletes' expectations and experiences with mindful sport performance enhancement. 
Journal of clinical sport psychology, 11(3), 201-221.

Moore A, \& Malinowski P. (2009). Meditation, mindfulness and cognitive flexibility. Consciousness and cognition, 18(1), 176-186.

Moran AP. (2016). The psychology of concentration in sport performers: A cognitive analysis. Psychology Press.

Myers A, Hansen CH. (2011). Experimental psychology. Cengage Leaming.

Park DC, Festini SB. (2016). A Cognitive Neuroscience Perspective. Cognitive Neuroscience of Aging: Linking Cognitive and Cerebral Aging.

Pashler H, Johnston JC, Ruthruff E. (2001). Attention and performance. Annual review of psychology, 52(1):629-51.

Perkins-Ceccato N, Passmore SR, \& Lee TD. (2003). Effects of focus of attention depend on golfers' skill. Journal of sports sciences, 21(8), 593600.

Pineau TR, Glass CR, \& Kaufman KA. (2014). Mindfulness in sport performance. The Wiley Blackwell handbook of mindfulness, 2, 1004 1033.

Pourtois G, Schettino A, \& VuilleumierP. (2013). Brain mechanisms for emotional influences on perception and attention: what is magic and what is not. Biological psychology, 92(3), 492512.

Reilly T, Richardson D, Stratton G, \& Williams AM. (2004). Youth soccer. From science to performance. Routledge.

Rooks JD, Morrison AB, Goolsarran M, Rogers SL, \& Jha AP. (2017). "We Are Talking About Practice": the Influence of Mindfulness vs. Relaxation Training on Athletes' Attention and Well-Being over High-Demand Intervals. Journal of Cognitive Enhancement, 1(2), 141153.

Stemberg RJ, Stemberg K. (2016). Cognitive psychology. Nelson Education.

Thompson RW, Kaufman KA, De Petrillo LA, Glass CR, \& Arnkoff DB. (2011). One year followup of mindful sport performance enhancement (MSPE) with archers, golfers, and runners.
Journal of Clinical Sport Psychology, 5(2), 99116.

Van De Water T, Huijgen B, Faber I, \& ElferinkGemser M. (2017). Assessing cognitive performance in badminton players: a reproducibility and validity study. Journal of human kinetics, 55(1), 149-159.

Verburgh L, Scherder EJ, van Lange PA, \& Oosterlaan J. (2014). Executive functioning in highly talented soccer players. PloS one, 9(3), e91254.

Vestberg T, Gustafson R, Maurex L, Ingvar M, \& Petrovic P. (2012). Executive functions predict the success of top-soccer players. PloS one, 7(4), e34731.

Zeidan F, Johnson SK, Diamond BJ, David Z, \& Goolkasian P. (2010). Mindfulness meditation improves cognition: Evidence of brief mental training. Consciousness and cognition, 19(2), 597-605.

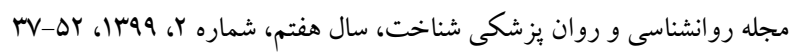

